\title{
Influences of Dimethyl Phthalate on Bacterial Community and Enzyme Activity in Vertical Flow Constructed Wetland
}

\author{
QiaoLing $X u^{1}$, ShaoYong Lu ${ }^{2}$, Tao Yuan ${ }^{3}$, Feng Zhang ${ }^{1}$, Li Wang ${ }^{1}$, Ping Wang ${ }^{1}$, XueYuan Wen ${ }^{1}$ and LiHua Cui ${ }^{4, *}$ \\ 1 Department of Resources \& Environmental Engineering, Anshun University, Anshun 561000, China; \\ amy.198510@163.com (Q.X.); zf19981123@sina.com (F.Z.); w113524678@sina.com (L.W.); \\ wp13648586718@sina.com (P.W.); wxy13479722858@sina.com (X.W.) \\ 2 Chinese Research Academy of Environmental Sciences, Beijing 100012, China; sylu@craes.org.cn \\ 3 State Key Laboratory of Nuclear Resources and Environment, School of Water Resources and \\ Environmental Engineering, East China University of Technology, Nanchang 330013, China; \\ taoyuan@ecut.edu.cn \\ 4 College of Natural Resource \& Environment, South China Agricultural University, Guangzhou 510642, China \\ * Correspondence: lihcui@scau.edu.cn
}

check for updates

Citation: $\mathrm{Xu}, \mathrm{Q}$; $\mathrm{Lu}, \mathrm{S}$.; Yuan, T.; Zhang, F.; Wang, L.; Wang, P.; Wen, X.; Cui, L. Influences of Dimethyl Phthalate on Bacterial Community and Enzyme Activity in Vertical Flow Constructed Wetland. Water 2021, 13, 788. https://doi.org/10.3390/ w13060788

Academic Editors: Pedro N. Carvalho and Víctor Matamoros

Received: 1 February 2021

Accepted: 11 March 2021

Published: 14 March 2021

Publisher's Note: MDPI stays neutral with regard to jurisdictional claims in published maps and institutional affiliations.

Copyright: (c) 2021 by the authors Licensee MDPI, Basel, Switzerland. This article is an open access article distributed under the terms and conditions of the Creative Commons Attribution (CC BY) license (https:// creativecommons.org/licenses/by/ $4.0 /)$.

\begin{abstract}
Dimethyl phthalate (DMP), belonging to the family of Phthalate esters (PAEs), is a plasticizer and has been widely used in the world for many years. Nowadays, it has become a ubiquitous environmental pollutant and is listed as an environmental priority pollutant by China's Environmental Monitoring Center. The purpose of this study is to estimate the responses of the bacterial community and enzyme activity to DMP contamination in three vertical flow constructed wetlands (VFCW), namely the constructed wetland A (planted with Pennisetum sinese Roxb), constructed wetland B (planted with Pennisetum purpureum Schum.), and constructed wetland C (unplanted), respectively. The results showed that the relative percentages of some genera associated with nitrogen metabolism and the function of degrading aromatic hydrocarbons were increased by DMP contamination, such as Dechloromonas agitata, Pleomorphomonas sp., Denitratisoma oestradiolicum, Plasticicumulans lactativorans, Novosphingobium sp., Alicycliphilus denitrificans, and Thauera sp. Meanwhile, principal coordinate analysis (PCA) analysis showed that the addition of DMP divided 12 samples into two groups as followed: one was the DMP group containing a-1, a-2, b-1, b-2, c-1 and c-2 while the other was no DMP group including A-1, A-2, B-1, B-2, C-1 and C-2. It indicated that DMP was the main reason for this change. In addition, by monitoring the activity of substrate enzymes, the activity of urease, phosphatase, catalase, and invertase in the wetlands before and after the experiment, these were significantly higher in the upper layer than in the lower layer and maintained high activity. Ultimately, the average influent concentration of DMP in three VFCWs was $8.12 \mathrm{mg} / \mathrm{L}$ and the average removal efficiency of the effluent was over $90 \%$. Our results suggested that DMP was an important factor affecting the microbial community structure of wetland and the upper layer of the VFCW was the main site for the degradation of DMP. VFCW has great potential for the removal of the high concentration of DMP and it can be a good choice for the treatment of PAEs.
\end{abstract}

Keywords: dimethyl phthalate (DMP); bacterial community; enzyme activity; vertical flow constructed wetland (VFCW)

\section{Introduction}

Constructed wetland $(\mathrm{CW})$ is a low-cost, eco-technology and a prospective wastewater treatment technology, which relies on biological, physical, and chemical processes to remove various pollutants [1]. In the past few years, vertical flow constructed wetland (VFCW) has become a preferable choice for wastewater treatment [2]. It showed good performance in removing nitrogen [3] and organic compounds [4,5] due to their excellent oxygen transfer characteristics and small area. Microorganisms play a key role in the 
treatment of pollutants in CW. In recent years, the related research studies on CW microorganisms mainly include the diversity of microorganisms [6], microbial enzyme activity [7], and the influence of environmental conditions (temperature, $\mathrm{pH}$, etc.) on microbial population and activity [8]. Some researchers propose that the number of microorganisms, bacterial diversity, and the activities of enzymes in the wetland are closely relevant to the removal of pollutants [9-11]. The traditional research methods for the microbial diversity of CW are mainly to separate, cultivate, and identify the microbial species through pure culture technology, but 85 99\% of the microorganisms in nature are not pure culture, so the traditional research methods may cause the wetland microbial diversity to be seriously underestimated [12]. In order to avoid the limitations of traditional methods, molecular biological analysis techniques, represented by polymerase chain reaction temperature gradient gel electrophoresis (PCR-TGGE) [13], polymerase chain reaction denaturing gradient gel electrophoresis (PCR-DGGE) [14,15], DNA molecular fingerprinting technology [16], and high-throughput sequencing technology [17], have been widely used in the study of microbial diversity in constructed wetlands in the field of environmental science. Phthalate esters (PAEs) have many types, complex properties, are mostly difficult to degrade, are not volatile, and have carcinogenic and mutation-causing characteristics, and potentially harmful to the environment characteristics, thus attracting wide attention [18]. Dimethyl phthalate (DMP), a known persistent organic pollutant and one of the PAEs, is a universal pollutant $[18,19]$. China has also classified dibutyl phthalate (DBP), dimethyl phthalate (DMP), and diester of phthalate (DEHP), as priority pollutants for environmental control in China. Liao et al. [20] reported that DMP, DBP, and DEHP were the main components of PAE pollutants in the soil of West Lake Scenic Spot that in Hangzhou city, Zhejiang Province, China, and the contribution rate of total content ranged from $95.65 \%$ to $99.22 \%$. PAEs can undergo a series of reactions, such as hydrolysis, adsorption, photochemical reactions, and microbial degradation in water. Under natural conditions, the main process of PAE disappearance in the environment should be the biodegradation reaction [21-23]. The content of PAEs in Chinese river water environments is usually in the order of $10^{-1}$ $10^{2} \mu \mathrm{g} / \mathrm{L}$ [24], but the concentration of PAEs in wastewater discharged from some chemical plants and nearby rivers is 10-300 ug/L, while the concentration of PAEs in wastewater discharged from plasticizer production plants is up to $30 \mathrm{mg} / \mathrm{L}$ [25]. In this study we used constructed wetland technology to treatment DMP with a concentration of $8.12 \mathrm{mg} / \mathrm{L}$. At present, there are few studies on the application of constructed wetlands in the treatment of PAEs [26-28], especially in the treatment of high-concentration PAES [26], and all of these have different removal effects. The main objectives of this study are: (1) study the effect of DMP on the microbial diversity and composition in VFCW; (2) understand the dominant bacterial in processing DMP and to determine enzyme activity for assessing the potential of DMP removal in VFCW.

\section{Materials and Methods}

\subsection{Construction of VFCW}

Three parallel VFCWs were constructed in the experiment, which were CW A (planted Pennisetum sinese Roxb), CW B (planted Pennisetum purpureum Schum.), CW C (unplanted). Each CW was a cement structure with a specification of $200 \mathrm{~cm}$ (length) $\times 100 \mathrm{~cm}$ (width) $\times 130 \mathrm{~cm}$ (height), as shown in Figure 1. Three CWs were irrigated effluents with three peristaltic pumps. Studies have shown that gravel was an ideal substrate for the treatment of dibutyl phthalate sewage [29], so the substrate in these CWs consisted mainly of grit. Three CWs were placed in barbed wire chambers with glass roofs. 


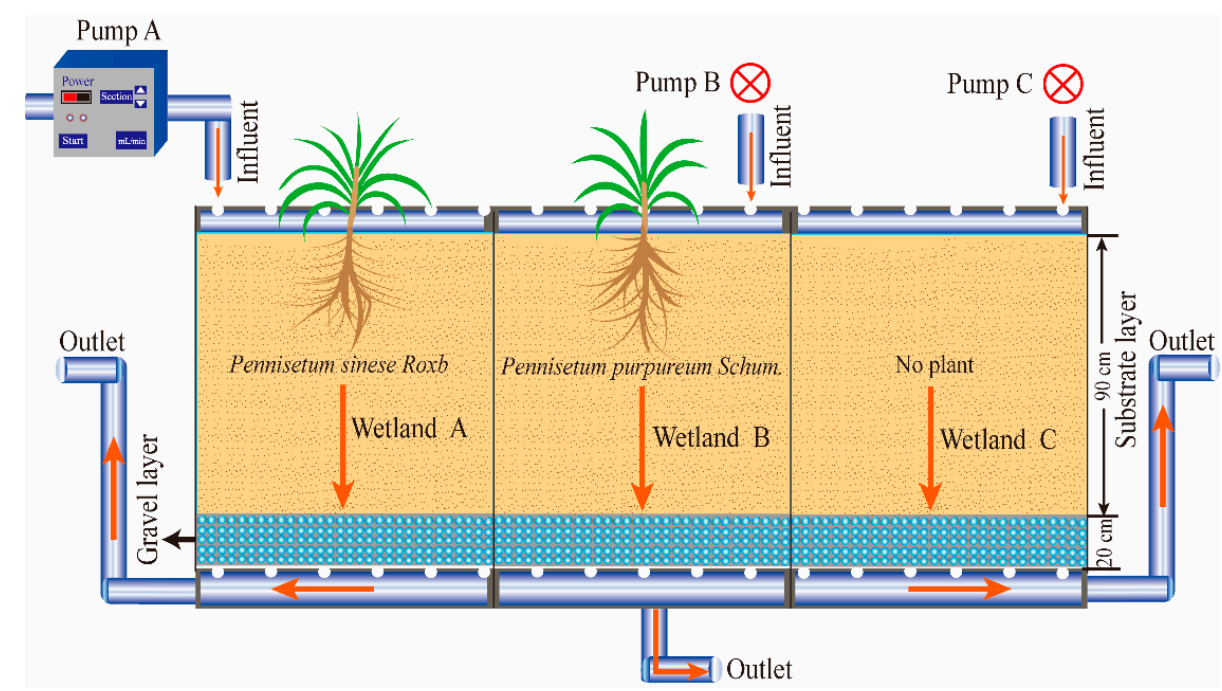

Figure 1. Schematic diagram of profile and plan of vertical flow constructed wetlands (VFCWs).

\subsection{Inflow Water Quality}

The experimental sewage is synthetic sewage, and the composition simulation is close to domestic sewage. Parameter values are as followed: the variation range of dissolved oxygen (DO) and $\mathrm{pH}$ values are $4-6 \mathrm{mg} / \mathrm{L}$ and 6.4-6.7. The average values of total nitrogen (TN), total phosphorous (TP), chemical oxygen demand (COD), and DMP are $40 \pm 5.5 \mathrm{mg} / \mathrm{L}, 4 \pm 1.1 \mathrm{mg} / \mathrm{L}, 330 \pm 40.9 \mathrm{mg} / \mathrm{L}$, and $8.12 \pm 0.69 \mathrm{mg} / \mathrm{L}$. The water quality indexes including of COD, TN, and TP are measured according to the national standard method. DMPs are analyzed by HPLC (Agilent 1260). Dimethyl phthalate standard $(>99.2 \%)$ is purchased from Merck. The UV detector analysis wavelength of the HPLC (Agilent 1260) is set at $254 \mathrm{~nm}$. The reversed phase chromatography is carried out on the EclipsexDB-C18 column with methanol and ultra-pure water mixture (50:50) as a mobile phase at a flow rate of $1.0 \mathrm{~mL} / \mathrm{min}$. The column temperature is constant at $23^{\circ} \mathrm{C}$. The automatic sampling system took $20 \mu \mathrm{L}$ samples at a time and injected them into the column for analysis. The relative standard deviation between the analysis results and the standard sample is less than $2 \%$.

\subsection{Operation and Management of VFCW}

Three VFCWs were carried out at $20 \mathrm{~cm} / \mathrm{d}$ hydraulic loading. The sewage contained DMP was added on the 15th of October; three systems were irrigated continuously with DMP sewage for $8 \mathrm{~h}$ every day. When the microorganism in the wetland is stable, the water quality monitoring work begins. On the 11th of November, we collected the water from the outlet position and analyzed every two weeks. This experiment ended on the 7th of February of the following year, with a total period of 114 days.

\subsection{Sample Collection and Analysis}

\subsubsection{Substrate Collection and Analysis}

The substrate sampling was made by sampling in a five-point method for analysis of microorganism and enzyme activity. Five points were collected for each wetland matrix, and each point was divided into two layers. The upper layer was $0-40 \mathrm{~cm}$, and the lower layer was $40-80 \mathrm{~cm}$. Finally, the same layer samples were mixed evenly to be the final substrate samples. Before the experiment, the upper layer substrate sample of the three wet systems were named by A-1, B-1, and C-1, respectively. The lower layer substrate sample of the three wet systems were named by A-2, B-2, and C-2, respectively. Similarly, at the end of experiment, the same method was adopted for substrate sampling. The upper layer of the three systems was numbered a-1, b-1, and c-1, and the lower layer was numbered a-2, $\mathrm{b}-2$, and c-2. Part of the substrate samples collected were stored in a refrigerator of $4{ }^{\circ} \mathrm{C}$ for the detection of enzyme activity, and other parts of the samples were stored in a refrigerator 
of $-40{ }^{\circ} \mathrm{C}$ for the experimental analysis of microbe. After the substrate was collected, the samples were sent to the laboratory with an ice box for subsequent extracting DNA.

\subsubsection{Methods for the Determination of Substrate Enzyme Activity}

Urease was determined by the phenol sodium-sodium hypochlorite colorimetric method. Phosphatase was determined by the phenyl phosphate disodium sodium colorimetric method. Catalase was determined by the potassium permanganate titration method and invertase was determined by the sodium thiosulfate titration method.

\subsubsection{Water Sample Collection and Analysis}

Water samples were collected every 14 days.

\subsection{Extraction and Detection of DNA from Soil Samples}

Mobio Power Soil DNA Isolation Kits (MO BIO Laboratories, Inc, Carlsbad, CA, USA) were selected to extract soil sample DNA. DNA was stored in an ultra-low temperature refrigerator at $-80^{\circ} \mathrm{C}$.

Under the condition of dry ice, soil sample DNA was sent to Beijing meiyimei biotechnology co., 1td. for PCR-DGGE detection. The V3 region sequence of 16S rRNA gene was amplified by GC-338F and 518R, the universal primers of bacteria. The amplification primer was 338F: 5'-CCT ACG GGA GGC AGC AG-3'; 518R: 5'-ATT ACC GCG GCT GCT GCT GG-3'; GC338F: 5'-CGC CCG GGG CGC GCC CCG GGG CGG GGC GGC GCG GGG GGC CTA CGG GAG GCA GCA G-3'. After the amplified DNA fragment was recovered and purified, it was connected to the Pmd18-T vector and transformed into the e. coli DH5 $\alpha$ receptor cells for positive cloning and sequence determination.

\subsection{Microbial Diversity and Richness Index}

The bacterial diversity index is a comprehensive index to study the number of species and the number of individuals of the community. According to the number of sample bands in the electrophoretic pattern and the intensity (gray scale) of each band, the indexes of bacteria in the Shannon-Wiener diversity index $(\mathrm{H})$, evenness index $(\mathrm{E})$, and richness index $(S)$ in each sample were analyzed. The calculation formula of each indicator is as follows:

$$
H^{\prime}=-\sum_{i=1}^{s}\left(p_{i} \ln p_{i}\right)=-\sum_{i=1}^{s}\left(N_{i} / \mathrm{N}\right) \ln \left(N_{i} / \mathrm{N}\right)
$$

In the formula, $p_{i}$ represents the ratio of the strength of a single strip in the sample to the total strength of all the strips in the sample. $\mathrm{N}$ represents the abundance of all the bands in a single lane of DGGE map. $N_{i}$ represents the abundance of band $i$. $S$ represents the sum of the number of bands in a sample.

\subsection{Statistical Analysis}

Quantity one software was used to analyze the number and density of each sample. GCTA software was used for PCA analysis. The statistical analyses were performed in Excel 2007 and SPSS(IBM) 26.0 software. Mean values and standard errors of correlation analysis were calculated. The Duncan method was used to analyze and compare the multiple comparisons. Because of the large scale of wetlands, no treatment duplication was set up, and the statistical analysis duplication in this paper is the absolute duplication of sampling.

\section{Results}

\subsection{DMP Removal in VFCW}

The DMP removal efficiency of the three wetlands was $100 \%$ on the 1 st of November and DMP could hardly be detected in the effluent. However, after two weeks, the removal rate of DMP dropped rapidly. After November 29th, the removal rate of DMP increased 
and became stable (Figure 2). At the end of experiment, the removal rate of DMP in these three CWs was more than $90 \%$. The three VFCWs all performed well in DMP removal.

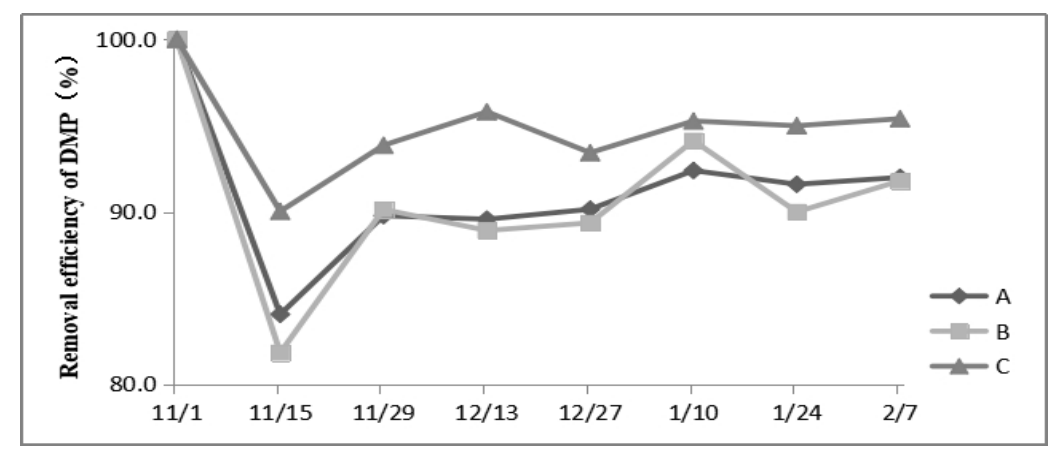

Figure 2. Dimethyl phthalate (DMP) removal efficiency in three VFCW.

\subsection{Dominant Microorganisms Based on DMP Contamination}

DGGE analysis of the PCR amplification products of each sample can be separated by the electrophoresis bands with different numbers and positions, so as to identify the differences of microbial community structure in the samples with different treatments. According to the principle that DGGE can be separated from DNA of the same length with different sequences, each stripe corresponds roughly to a dominant flora or Operational Taxonomic Unit (OTU) in the community. The fluorescence intensity after the band staining reflects the abundance of this type of bacteria. The brighter the stripe signal, the more bacteria there are in the genus. Consequently, it reflects the species and quantity of bacteria in the wetland. The analysis results of DGGE gel electrophoresis (Figure 3) showed that there were 40 types of dominant bacterial flora in CWs, and analyses the DGGE gel bands recovery sequence (Table 1). Generally, the homology of $16 \mathrm{~S}$ rDNA sequence is less than $98 \%$, which can be considered as belonging to different species of bacteria. If the homology is less than $93-95 \%$, it can be considered as belonging to different genera. DMP was added into $\mathrm{CW}$ to induce the growth and reproduction of the microbial community related to the decomposition of the substance. The results indicated that after adding DMP in these three CWs, the dominant bacteria in substrate were Dechloromonas agitata, Labilithrix luteola, Plasticicumulans lactativorans, Pleomorphomonas sp., Novosphingobium sp., Denitratisoma oestradiolicum, Alicycliphilus denitrificans, Thauera sp., and Levilinea saccharolytica. From the view of microorganism, VFCW has great potential to degrade DMP.

Table 1. BLAST results of selected DGGE bands from the DGGE profiles.

\begin{tabular}{ccccc}
\hline Band Number & $\begin{array}{c}\text { Length of } \\
\text { Fragment (bp) }\end{array}$ & Closest Related Strain & $\begin{array}{c}\text { Accession } \\
\text { Number }\end{array}$ & $\begin{array}{c}\text { Similarity } \\
\text { (\%) }\end{array}$ \\
\hline Band1 (B-1) & 169 & Uncultured bacterium & KF182847 & 100 \\
Band2 (C-1) & 193 & uncultured Verrucomicrobiales bacterium & LN625193 & 97 \\
Band3 (b-1) & 194 & Dechloromonas agitata & KF800710 & 100 \\
Band4 (B-1) & 169 & Uncultured bacterium & AB661277 & 100 \\
Band5 (C-1) & 194 & Thauera sp. & AB757831 & 100 \\
Band6 (A-1) & 194 & Chlamydiales bacterium & JN606074 & 96 \\
Band7 (c-1) & 193 & Labilithrix luteola & 126182 & 97 \\
Band11 (c-1) & 189 & Prevotellaceae bacterium & AB298732 & 98 \\
Band13 (b-1) & 194 & Nlasticicumulans lactativorans & KF983816 & 99 \\
Band14 (b-2) & 169 & Pleomorphomonas sp. & KJ194928 & 100 \\
Band18 (A-1) & 169 & Clostridium beijerinckii & KP284177 & 99 \\
Band23 (c-1) & 169 & Novosphingobium sp. & KP076216 & 98 \\
Band24 (C-1) & 189 & Chitinophaga terrae & NR_126180 & 97 \\
Band28 (C-1) & 169 & Reyranella graminifolii & KJ461512 & 99 \\
Band29 (c-2) & 194 & Uncultured bacterium & KF810120 & 98 \\
Band32 (b-1) & 194 & Denitratisoma oestradiolicum & GU738861 & 97 \\
Band33 (B-2) & 173 & Uncultured bacterium & KM210246 & 100 \\
Band35 (b-1) & 194 & Alicycliphilus denitrificans & AB920830 & 99 \\
Band39 (a-2) & 194 & Thauera sp. & NR_040972 & 99 \\
Band40 (b-2) & 170 & Levilinea saccharolytica & \\
\hline Note:Bands
\end{tabular}

Note: Bands are numbered according to Figure 3. Similarity represents the percentage identity shared with the sequences in the GenBank databases. 


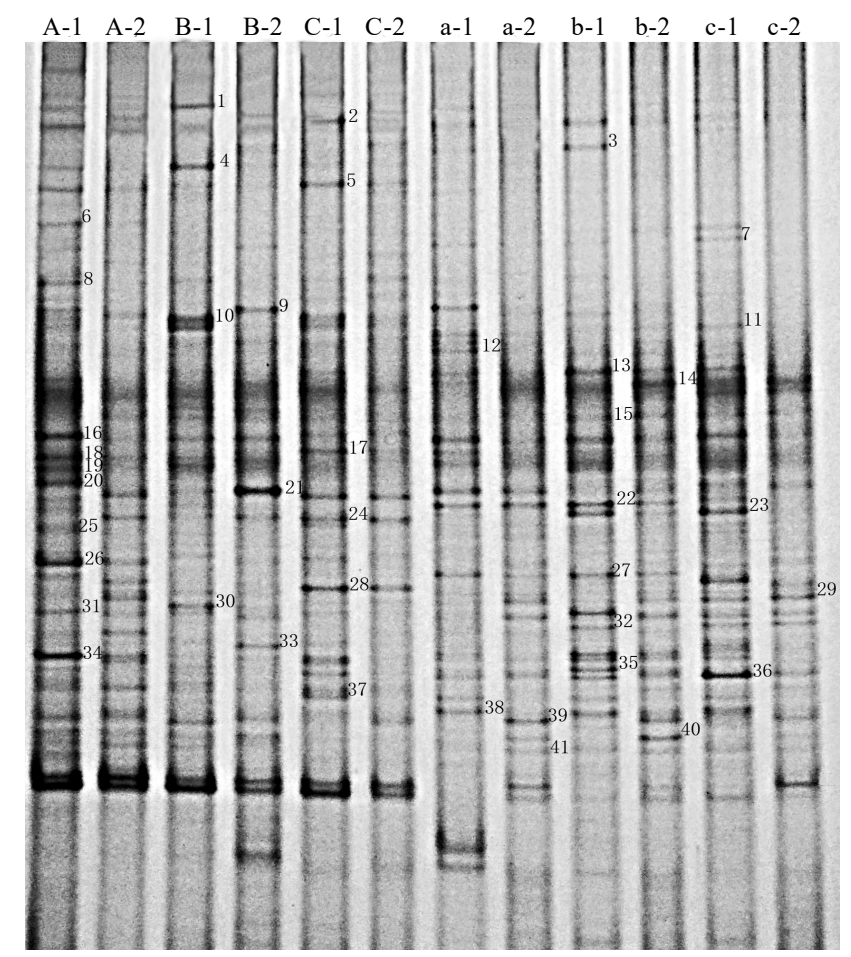

Figure 3. Denaturing gradient gel electrophoresis (DGGE) profile of $16 \mathrm{~S}$ rDNA V3 fragments amplified from a microbial community of three wetlands. (Note: A-1, A-2, B-1, B-2, C-1 and C2 were substrate samples before adding DMP in the three constructed wetlands (CWs). The samples of a-1, a-2, b-1, b-2, c-1, and c-2 were substrate samples after adding DMP in the three CWs. In the sample code, the uppercase English letter refers to the sample before adding DMP, and the lowercase letter refers to the sample after adding DMP (the letters A and a represent the wetland A of planted Pennisetum sinese Roxb; B and b represent the wetland B of planted Pennisetum purpureum Schum.; $C$ and $c$ represent the blank control wetland $C$; the Arabic numerals represent the sampling depth: 1 represents the upper substrate of $0-40 \mathrm{~cm}$, and 2 represents the lower layer substrate of $40-80 \mathrm{~cm}$. Serial numbers correspond to bands excised from the DGGE and sequenced results are listed in Table 1).

\subsection{Microbial Community Grouping Based on DMP Contamination}

DMP has a great influence on bacterial diversity in the substrate of VFCW (Figure 4). Each point in the figure represents a sample, and the same color points are from same wetland. The closer the distance between the two points, the smaller the difference in community composition between the two points; otherwise, the greater the difference. Principal coordinate analysis (PCA) was conducted to investigate the dissimilarities among the 12 samples. The first axis explained $27.6 \%$ variance of species and $25.3 \%$ was explained by the second axis. These 12 samples formed two groups as follows: one was the DMP group containing a-1, a-2, b-1, b-2, c-1, and c-2 while the other was no DMP group including A-1, A-2, B-1, B-2, C-1, and C-2. Seen from Figure 4, there was a high similarity among these samples of each group, while there was a great difference in the similarity among the groups. It indicated that the microbial flora structure changed, and the samples before and after the experiment showed different flora compositions, which were directly related to the presence or absence of DMP. Seen from Table 2, Shannon-Wiener and richness of 12 samples all showed the same rule: the upper layer was higher than the lower layer, and the addition of DMP has different effects on the three wetlands. Adding DMP reduced the microbial diversity of the planted vegetation wetland and increased the microbial diversity of the unplanted wetland. This also proved that planting vegetation contributes to the construction of wetland microbial community diversity, and the addition of DMP can narrow the microbial diversity gap between planted vegetation wetland and unplanted 
wetland. In the future, we can further study the long-term effects of DMP on constructed wetland vegetation.

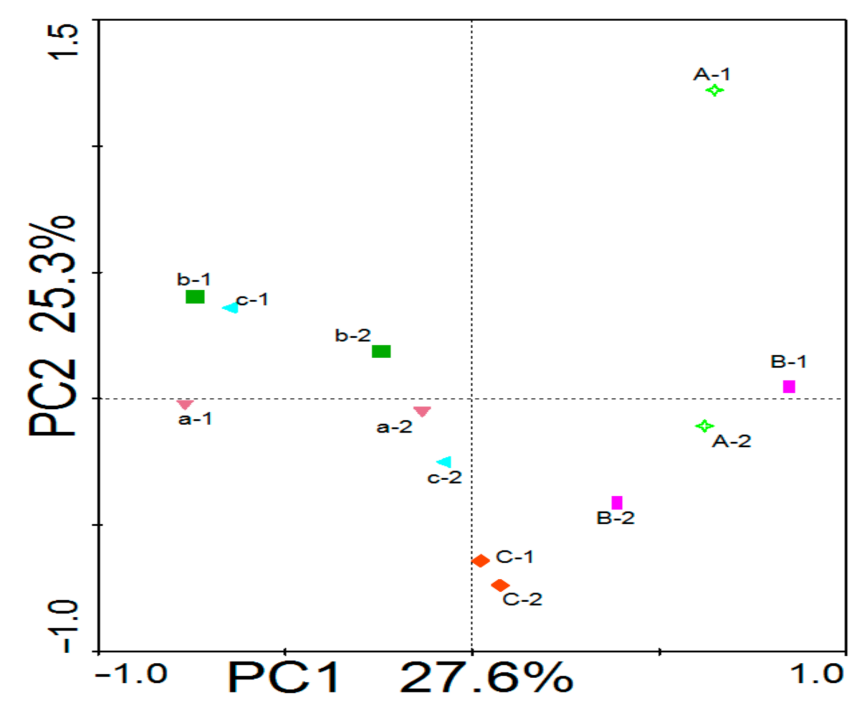

Figure 4. Principal coordinate analysis (PCA) score plot of different wetland samples based on weighted UniFrac metrics. Two categories were clustered, including the DMP group and the NO DMP group.

Table 2. Shannon-Wiener diversity and richness index of substrate in VFCW.

\begin{tabular}{ccc}
\hline Samples & Shannon-Wiener & Richness \\
\hline A-1 & 3.33 & 29 \\
A-2 & 3.22 & 26 \\
B-1 & 3.38 & 31 \\
B-2 & 3.07 & 23 \\
C-1 & 3.08 & 23 \\
C-2 & 2.73 & 16 \\
a-1 & 3.13 & 24 \\
a-2 & 3.00 & 21 \\
b-1 & 3.23 & 27 \\
b-2 & 3.30 & 28 \\
c-1 & 3.30 & 29 \\
c-2 & 2.90 & 19 \\
\hline
\end{tabular}

\subsection{Substrate Enzyme Activity Based on DMP Contamination}

The activity of these enzymes in the substrate had the same changed rules, all of which showed that the enzyme activities of the substrate at upper layer were significantly higher than those at the lower layer $(p=0.000<0.01)$. The enzyme activities showed a negative correlation with depth. In this study, the activities of urease, phosphatase, catalase, and invertase in VFCW after adding DMP were higher than that of those before adding DMP. At the end of experiment, the urease, phosphatase, catalase, and invertase activities at upper layer of the three wetlands reached up to $172.8 \mu \mathrm{g} /(\mathrm{g} \cdot 24 \mathrm{~h}), 98.3 \mu \mathrm{g} /(\mathrm{g} \cdot 24 \mathrm{~h}), 0.0223 \mathrm{nmol} / \mathrm{g}$, $1.92 \mathrm{~mL} /(\mathrm{g} \cdot 24 \mathrm{~h})$, respectively. Before adding DMP, these enzyme activities in wetlands were $99.8 \mu \mathrm{g} /(\mathrm{g} \cdot 24 \mathrm{~h}), 79.8 \mu \mathrm{g} /(\mathrm{g} \cdot 24 \mathrm{~h}), 0.022 \mathrm{nmol} / \mathrm{g}, 0.91 \mathrm{~mL} /(\mathrm{g} \cdot 24 \mathrm{~h})$ respectively. In general, the enzyme activity and microbial metabolism of the three wetlands were active in the experimental period.

\section{Discussion}

PAEs, as a kind of environmental endocrine disruptor, have potential threat to human health $[30,31]$ and ecological environment. As a sewage treatment technology, CW has been 
used to treat various types of sewage, but its removal efficiency of PAEs, especially the high concentration PAEs, has been rarely studied [28]. DMP, a known persistent organic pollutant and one of the PAEs, is a universal pollutant [18]. The removal rate of DMP analysis showed that the DMP removal efficiency of the three wetlands was $100 \%$ on the 1st of November; however, the removal rate of DMP has been decreased on the 15th of November. After November 29th, the removal rate of DMP increased and tended to be stable. That is because substrate adsorbed DMP significantly at the beginning of VFCW operation. However, when the substrate adsorption tends to saturation, the DMP removal rate decreased sharply, and the ability of the wetland to remove DMP will not be restored until the microorganisms in the wetland reach a stable state. Some studies have shown that under natural conditions, the main process of PAEs disappearance in the environment should be a biodegradation reaction $[18,28]$. As an ecological treatment technology, a constructed wetland should have a certain ability to remove PAEs. Previous study has shown that the influent concentrations of DBP in the composite wetland were $9.84 \mathrm{mg} / \mathrm{L}$ and the average removal efficiency of effluent was over 79\% [26], while in reed bed sewage treatment process, the removal rate of diethyl phthalate (DEP) was as high as 94-99\% [32], which was similar to our study. In our study, the removal rates of DMP in these three CWs were more than $90 \%$. That is due to the fact that there were some functional bacteria and active enzymes in these three wetlands (seen from Tables 1 and 3).

Table 3. Enzyme activity of substrate in the three VFCWs.

\begin{tabular}{|c|c|c|c|c|c|c|}
\hline & & & \multicolumn{2}{|c|}{ Before Adding DMP } & \multicolumn{2}{|c|}{ After Adding DMP } \\
\hline & & & Upper Layer & Lower Layer & Upper Layer & Lower Layer \\
\hline \multirow{3}{*}{ urease activity } & \multirow{3}{*}[\mu\mathrm{g}/(\mathrm{g}\cdot24\mathrm{h})]{} & $\mathrm{A}$ & $99.8 \pm 7.08^{b}$ & $10.2 \pm 1.34^{\mathrm{a}}$ & $172.8 \pm 4.39^{\mathrm{a}}$ & $25.8 \pm 1.27^{\mathrm{b}}$ \\
\hline & & B & $124.5 \pm 4.27^{\mathrm{a}}$ & $14.2 \pm 6.82^{\mathrm{a}}$ & $167.7 \pm 2.77^{\mathrm{a}}$ & $30.1 \pm 3.03^{\mathrm{ab}}$ \\
\hline & & $\mathrm{C}$ & $80.5 \pm 2.18^{c}$ & $8.1 \pm 1.26^{\mathrm{a}}$ & $150.8 \pm 2.50^{b}$ & $32.9 \pm 2.18^{a}$ \\
\hline \multirow{3}{*}{$\begin{array}{c}\text { phosphatase } \\
\text { activity }\end{array}$} & \multirow{3}{*}[\mu\mathrm{g}/(\mathrm{g}\cdot24\mathrm{h})]{} & $\mathrm{A}$ & $79.8 \pm 14.52^{a}$ & $0.3 \pm 0.16^{\mathrm{a}}$ & $98.3 \pm 0.12^{b}$ & $4.8 \pm 0.14^{b}$ \\
\hline & & $\mathrm{B}$ & $82.4 \pm 3.78^{a}$ & $0.2 \pm 0.09^{a}$ & $102.4 \pm 2.26^{\mathrm{a}}$ & $6.7 \pm 0.41^{\mathrm{a}}$ \\
\hline & & $\mathrm{C}$ & $42.2 \pm 18.28^{b}$ & $0.1 \pm 0.03^{a}$ & $86.3 \pm 2.15^{c}$ & $2.8 \pm 0.11^{c}$ \\
\hline \multirow{3}{*}{ catalase activity } & \multirow{3}{*}{$(\mathrm{nmol} / \mathrm{g})$} & $\mathrm{A}$ & $0.0211 \pm 0.001^{\mathrm{a}}$ & $0.009 \pm 0.003^{a}$ & $0.0223 \pm 0.0012^{\mathrm{a}}$ & $0.0077 \pm 0.0009^{a}$ \\
\hline & & $\mathrm{B}$ & $0.022 \pm 0.003^{\mathrm{a}}$ & $0.007 \pm 0.001^{a b}$ & $0.0213 \pm 0.000^{\mathrm{ab}}$ & $0.0071 \pm 0.0002^{a}$ \\
\hline & & $\mathrm{C}$ & $0.017 \pm 0.003^{\mathrm{a}}$ & $0.004 \pm 0.001^{\mathrm{b}}$ & $0.0205 \pm 0.0002^{b}$ & $0.0067 \pm 0.0008^{a}$ \\
\hline \multirow{3}{*}{ invertase activity } & \multirow{3}{*}[\mathrm{mL}/(\mathrm{g}\cdot24\mathrm{h})]{} & $\mathrm{A}$ & $0.91 \pm 0.085^{\mathrm{a}}$ & $0.01 \pm 0.005^{b}$ & $1.92 \pm 0.05^{\mathrm{a}}$ & $0.90 \pm 0.10^{\mathrm{ab}}$ \\
\hline & & $\mathrm{B}$ & $0.84 \pm 0.392^{a}$ & $0.2 \pm 0.087^{\mathrm{a}}$ & $1.85 \pm 0.03^{\mathrm{a}}$ & $1.0 \pm 0.17^{\mathrm{a}}$ \\
\hline & & $\mathrm{C}$ & $0.48 \pm 0.087^{\mathrm{a}}$ & $0.10 \pm 0.065^{\mathrm{ab}}$ & $1.85 \pm 0.04^{\mathrm{a}}$ & $0.73 \pm 0.08^{b}$ \\
\hline
\end{tabular}

Note: Mean \pm standard deviation, where $a, b$, and $\mathrm{c}$ in the table represent the significant differences among different CWs, respectively.

Microorganisms are the most important drivers of soil biochemical processes and are very sensitive to changes in the soil environment, which can be used for evaluation changes in soil quality during pollution [32]. Microbial sequencing and cluster analysis were performed to analyze the structure of the microbial community in 12 samples of three wetlands. PCA analysis showed bacterial communities in the 12 samples were divided into two groups: the no DMP group and the DMP group. This result indicated that DMP could be the important factor altering microbial community structure. This is similar to a previous study in DMP contamination on abundance and diversity of microbes in black soil $[18,33]$. There are a large number of functional microbial flora in the soil, which catalyze the biochemical reactions in the soil and directly participate in the cycling process of nutrient elements [34,35]. Their quantity and activity are directly related to the ecosystem function of the soil. The results of the author's experiments showed that some functional bacteria appeared, such as, Dechloromonas agitata [36], Pleomorphomonas sp. [37], and Denitratisoma oestradiolicum [38]. These bacteria were involved in the nitrogen cycle and became the dominant bacteria in the DMP treatment wetland, indicating that the high concentration of DMP had a positive effect on the microorganisms involved in the nitrogen cycle in the CW. Meanwhile, Plasticicumulans lactativorans [39], Novosphingobium sp. [40], 
Alicycliphilus denitrificans [41], and Thauera sp. [42] have the ability to degrade polycyclic aromatic hydrocarbon compounds and can be widely used in sewage treatment as the dominant flora. It also showed that DMP could be used as a carbon source to facilitate the growth and reproduction of related functional microorganisms. Some studies showed that the inhibitory effect of phthalates on microorganisms was enhanced with the increase of pollutant mass fractions, showing a good dose-effect relationship [43,44]. Meanwhile, as a biocatalyst, the enzyme in CW plays an important role in the decomposition of organic pollutants. It has been found that microorganisms and substrate enzymes play a key role in the treatment of organic pollutants in composite VFCWs [26]. These reported that soil enzymes can accelerate the chemical reaction of organic substances [45]. Dehydrogenase, catalase, phosphatase, urease, protease, and other enzymes in the soil can be responded to PAEs $[43,46-48]$. In the enzyme activity analysis that was performed after adding DMP, the urease, phosphatase, catalase, and invertase activity in wetlands did not decrease; on the contrary, these enzyme activities after adding DMP were higher than those before adding DMP in the three wetlands. It is similar with the study on the increase of enzyme activities of urease, phosphatase, and dehydrogenase that was observed in the treatments with DBP addition [49]. At the same time, the enzyme activities of the substrate at the upper layer are significantly higher than those at the lower layer $(p=0.000<0.01)$, and the microbial diversity in the upper layer is also higher than at the lower layer (Table 2). This result is similar to previous studies in which with the increasing substrate depth, the enzyme activity decreased, and the number of bacteria reflected by the spatial law was consistent with the enzyme activity [50].

\section{Conclusions}

(1) The results of this study demonstrated that DMP could change the bacterial community structure, and increase the relative percentages of some genera associated with nitrogen metabolism and the function of degrading aromatic hydrocarbons, such as Dechloromonas agitata, Pleomorphomonas sp., Denitratisoma oestradiolicum, Plasticicumulans lactativorans, Novosphingobium sp., Thauera sp., and Alicycliphilus denitrificans. It showed that DMP $(8.12 \mathrm{mg} / \mathrm{L})$ could be used as a carbon source to facilitate the growth and reproduction of some functional microorganisms. In the future, we will further study the influence of different concentration levels of DMP on wetland microorganisms.

(2) DMP maintained the higher activities of urease, phosphatase, catalase, and invertase in these three CWs, and stronger activities of these four enzymes occurred at the upper layer of the three CWs. In addition, the activities of urease, phosphatase, catalase, and invertase in the upper layer are significantly higher than in the lower layer, indicating that VFCW has great potential to degrade high concentration DMP. Furthermore, at the end of the experiment, the removal rates of DMP in these three CWs are more than $90 \%$.

(3) The results also showed that the upper layer is the main site for the degradation of DMP. It provides theoretical and data support for the treatment of DMP in CWs.

Author Contributions: Writing original draft preparation, Q.X.; Data analysis, T.Y., L.W., F.Z., P.W. and X.W.; supervision, L.C. and S.L. All authors have read and agreed to the published version of the manuscript.

Funding: This research received Guizhou Provincial Support Program for Top Talents in Science and Technology in Colleges (QIANJIAOHEKY[2016]097), Guizhou Provincial Science and Technology Plan Project (QIANJIAOHELHZI[2016]7283), Anshun College Ph.D. Fund Project (asubsjj 2016) No. 07, National Natural Science Foundation of China (41271245).

Institutional Review Board Statement: Not applicable.

Informed Consent Statement: Not applicable.

Data Availability Statement: The data presented in this study are available in the article. 
Acknowledgments: The authors wish to thank Lin Jingxing, a professor at the Chinese Academy of Geological Sciences, for his help in polishing the language of this article, and thank all reviewers for their valuable comments, which greatly helped in improving the quality of the final manuscript.

Conflicts of Interest: The authors declare no conflict of interest.

\section{References}

1. Tang, P.; Yu, B.H.; Zhou, Y.C.; Zhang, Y.P.; Li, J. Clogging development and hydraulic performance of the horizontal subsurface flow storm water constructed wetlands: A laboratory study. Environ. Sci. Pollut. Res. 2017, 24, 9210-9219. [CrossRef]

2. Zhou, X.; Gao, L.; Zhang, H.; Wu, H.M. Determination of the optimal aeration for nitrogen removal in biochar-amended aerated vertical flow constructed wetlands. Bioresour. Technol. 2018, 261, 461-464. [CrossRef] [PubMed]

3. Xu, Q.L.; Huang, Z.J.; Wang, X.M.; Cui, L.H. Pennisetum sinese Roxb and Pennisetum purpureum Schum. as vertical-flow constructed wetland vegetation for removal of $\mathrm{N}$ and P from domestic sewage. Ecol. Eng. 2015, 83, 120-124. [CrossRef]

4. Cooper, P. The performance of vertical flow constructed wetland systems with special reference to the significance of oxygen transfer and hydraulic loading rates. Water Sci. Technol. 2005, 51, 81-90. [CrossRef] [PubMed]

5. Xu, Q.L.; Cui, L.H. Removal of COD from synthetic wastewater in vertical flow constructed wetland. Water Environ. Res. 2019, 91, 1661-1668. [CrossRef] [PubMed]

6. $\quad$ Long, Y.; Yi, H.; Chen, S.L.; Zhang, Z.K.; Cui, K.; Bing, Y.X.; Zhuo, Q.F.; Li, B.X.; Xie, S.G.; Guo, Q.W. Influences of plant type on bacterial and archaeal communities in constructed wetland treating polluted river water. Environ. Sci. Pollut. Res. 2016, 23, 19570-19579. [CrossRef]

7. Wu, Z.B.; Liang, W.; Cheng, S.P.; He, F.; Fu, G.P. Studies on correlation between the enzymatic activities in the rhizosphere and purification of wastewater in the constructed wetland. Acta Sci. Circumst. 2001, 21, 622-624.

8. Faulwetter, J.L.; Burr, M.D.; Parker, A.E.; Stein, O.R.; Camper, A.K. Influence of season and plant species on the abundance and diversity of sulfate reducing bacteria and ammonia oxidizing bacteria in constructed wetland microcosms. Microb. Ecol. 2013, 65, 111-127. [CrossRef] [PubMed]

9. Bachand, P.A.M.; Horne, A.J. Denitrifcation in constructed free-water surface wetlands: I. Very high nitrate removal rates in a macrocosm study. Ecol. Eng. 2000, 14, 9-15. [CrossRef]

10. Shackle, V.J.; Freeman, C.; Reynolds, B. Carbon supply and the regulation of enzyme activity in constructed wetlands. Soil Biol. Biochem. 2000, 32, 1935-1940. [CrossRef]

11. Stottmeister, U.; Wießner, A.; Kuschk, P.; Kappelmeyer, U.; Kästner, M.; Bederski, O.; Müller, R.A.; Moormann, H. Effects of plants and microorganisms in constructed wetlands for wastewater treatment. Biotechnol. Adv. 2003, 22, 93-117. [CrossRef] [PubMed]

12. Liang, Y.J.; Luo, X.N.; Fu, H.X. Application of PCR-DGGE technique in microbial ecology. J. Biol. 2007, 24, 58-60.

13. Liu, Z.W.; Zhou, M.X.; Song, J.L.; Guo, Z.W. Analysis of pollutant removal characteristics and microbial community diversity of composite vertical flow constructed wetland. Environ. Eng. 2014, 6, 38-42.

14. Truu, J.; Nurk, K.; Juhanson, J.; Mander, U. Variation of microbiological parameters within planted soil filter for domestic wastewater treatment. J. Environ. Sci. Health 2005, 40, 1191-1200. [CrossRef] [PubMed]

15. Menon, R.; Jackson, C.R.; Holland, M.M. The influence of vegetation on microbial enzyme activity and bacterial community structure in freshwater constructed wetland sediments. Wetlands 2013, 33, 365-378. [CrossRef]

16. Sleytr, K.; Tietz, A.; Langergraber, G.; Haberl, R.; Sessitsch, A. Diversity of abundant bacteria in subsurface vertical flow constructed wetlands. Ecol. Eng. 2009, 35, 1021-1025. [CrossRef]

17. Hua, G.F.; Cheng, Y.; Kong, J.; Li, M.; Zhao, Z.W. High-throughput sequencing analysis of bacterial community spatiotemporal distribution in response to clogging in vertical flow constructed wetlands. Bioresour. Technol. 2017, 248, 104-112. [CrossRef] [PubMed]

18. Wang, Z.G.; Hu, Y.L.; Xu, W.H.; Liu, S.; Hu, Y.; Zhang, Y. Impacts of dimethyl phthalate on the bacterial community and functions in black soils. Front. Microbiol. 2015, 6, 1-11. [CrossRef]

19. Liu, C.; Sun, C.Z.; Zhang, G.; Tang, L.; Zou, Y.D.; Xu, Q.Q.; Li, F.M. Pollution characteristics and ecological risk assessment of phthalate esters (PAEs) in surface water of Jiaozhou Bay. Chin. J. Environ. Sci. 2019, 40, 1-18. [CrossRef]

20. Liao, J.; Deng, C.; Chen, Y.; Zhou, W.Z.; Lin, C.M.; Zhang, H. Pollution Levels, Sources, and Spatial Distribution of Phthalate Esters in Soils of the West Lake Scenic Area. Chin. J. Environ. Sci. 2019, 40, 3378-3387.

21. Stales, C.A.; Peterson, D.R.; Parkerton, T. The environmental fate of phthalate esters: A literature review. Chemosphere 1997, 35, 667-749. [CrossRef]

22. Cheung, J.K.H.; Lam, R.K.W.; Shi, M.Y.; Gu, J.D. Environmental fate of endocrine-disrupting dimethyl phthalate esters (DMPE) under sulfate-reducing condition. Sci. Total Environ. 2007, 381, 126-133. [CrossRef]

23. Liang, H.H.; Wang, Y.J.; Tao, H.; Zhang, X.H. Isolation, identification and degradation characteristics of a three phthalates degrading bacterium. Environ. Chem. 2019, 38, 2808-2818.

24. Chen, H. Study on the Pollution Level of Typical Phthalates in Environmental Water and Reproductive Toxicity of Combined Exposure in Zebrafish; Jiangsu University: Zhenjiang, China, 2020; pp. 3-4.

25. Li, Y.R. Removal and Control of Phthalic acid Esters from Domestic Wastewater; Shandong Jianzhu University: Jinan, China, 2016; pp. $4-5$. 
26. Wu, Z.B.; Zhao, W.Y.; Cheng, S.P.; Zhou, Q.H.; He, F.; Fu, G.P. Preliminary studies on purification of Di-butyl phthalate (DBP) by integrated vertical constructed wetlands. Environ. Chem. 2002, 21, 495-499.

27. Liang, W.; Deng, J.Q.; Zhan, F.C.; Wu, Z.B. Effects of constructed wetland system on the removal of dibutyl phthalate (DBP). Microbiol. Res. 2009, 164, 20-26. [CrossRef] [PubMed]

28. Zhao, X.; Liu, M.X.; Zheng, L.; Chen, C.; Ding, A.Z. Phthalate acid ester removal efficiency in horizontal subsurface flow constructed wetland. J. Beijing Norm. Univ. Nat. Sci. 2017, 53, 301-307.

29. Li, T.C.; Fan, Y.C.; Cun, D.S.; Dai, Y.R.; Liang, W. Dibutyl phthalate adsorption characteristics using three common substrates in aqueous solutions. Front. Environ. Sci. Eng. 2020, 14, 139-149. [CrossRef]

30. Tao, S.M.; Zhu, D.L.; Chen, Y.H.; Wu, H.Q.; Zhou, X.; Xu, C.Z.; Xie, Z.Z.; Tao, L.; Xi, Y. Investigation on Exposure Levels of Phthalates in Human Plasma Collected from the Pearl River Delta. J. Instrum. Anal. 2019, 38, 315-1320.

31. Chen, N.; Shuai, W.J.; Hao, X.M.; Zhang, H.C.; Zhou, D.M.; Gao, J. Contamination of phthalate esters in vegetable agriculture and human cumulative risk assessment. Pedosphere 2017, 27, 439-451. [CrossRef]

32. Oliver, R.; May, E.; Williams, J. The occurrence and removal of phthalates in a trickle filter STW. Water Res. 2005, 39, 4436-4444. [CrossRef]

33. Zhu, X.H.; Liu, H.; Guo, R.X.; Wang, H.X.; Wang, Z.G. Response of microbial community in black soil to remediation of dimethyl phthalate contaminated soil by Paracoccus sp. QD15-1. Environ. Poll. Control 2020, 42, 182-186.

34. Blagodatskaya, E.; Kuzyakov, Y. Active microorganisms in soil: Critical review of estimation criteria and approaches. Soil Biol. Biochem. 2013, 67, 192-211. [CrossRef]

35. Mahapatra, B.; Adak, T.; Patil, N.K.B.; Pandi, G.P.G.; Gowda, G.B.; Jambhulkar, N.N.; Yadav, K.M.; Panneerselvam, P.; Kumar, U.; Munda, S.; et al. Imidacloprid application changes microbial dynamics and enzymes in rice soil. Ecotox. Environ. Saf. 2017, 44, 123-130. [CrossRef]

36. Achenbach, L.A.; Michaelidou, U.; Bruce, R.A.; Fryman, J.; Coates, J.D. Dechloromonas agitata gen. Nov., sp. Nov. and Dechlorosoma suillum gen. Nov., sp. Nov., Two novel environmentally dominant (per)chlorate-reducing bacteria and their phylogenetic position. Int. J. Syst. Evol. Microbiol. 2001, 51, 527-533. [CrossRef] [PubMed]

37. Xie, C.H.; Yokota, A. Pleomorphomonas oryzae gen. Nov., Sp. Nov., A nitrogen-fixing bacterium isolated from paddy soil of Oryza sativa. Int. J. Syst. Evol. Microbiol. 2005, 55, 1233-1237. [CrossRef]

38. Fahrbach, M.; Kuever, J.; Meinke, R.; Kampfer, P.; Hollender, J. Denitratisoma oestradiolicum gen. Nov., Sp. Nov., A 17betaoestradiol-degrading, denitrifying betaproteobacterium. Int. J. Syst. Evol. Microbiol. 2006, 56, 1547-1552. [CrossRef]

39. Jelmer, T.; Kätlin, L.; Yang, J.; Loosdrecht, M.C.M.V.; Robbert, K. Enrichment of Plasticicumulans acidivorans at pilot-scale for PHA production on industrial wastewater. J. Biotechnol. 2014, 192, 161-169.

40. Tiirola, M.A.; Männistö, M.K.; Puhakka, J.A.; Kulomaa, M.S. Isolation and characterization of novosphingobium sp. Strain MT1, a dominant Polychlorophenol-Degrading strain in a groundwater bioremediation system. Appl. Environ. Microbiol. 2002,68, 173-180. [CrossRef] [PubMed]

41. Ntougias, S.; Melidis, P.; Navrozidou, E.; Tzegkas, T. Diversity and efficiency of anthracene-degrading bacteria isolated from a denitrifying activated sludge system treating municipal wastewater. Int. Biodeterior. Biodegrad. 2015, 97, 151-158. [CrossRef]

42. Danh, H.D. Anaerobic degradation of 2,4-dichlorophenoxyacetic acid by Thauera sp. DKT. Biodegradation 2018, $29,499-510$.

43. Gao, J.; Chen, B.Q. Effects of PAEs on soil microbial activity and catalase activity. J. Soil Water Conserv. 2008, 22, 166-169.

44. Guo, Y.; Han, R.; Du, W.T.; Wu, J.W.; Liu, W. Effects of Combined Phthalate Acid Ester Contamination on Soil Micro-Ecology. Res. Environ. Sci. 2010, 23, 1410-1414.

45. Gianfreda, L.; Rao, M.A.; Piotrowska, A.; Palumbo, G.; Colombo, C. Soil enzyme activities as affected by anthropogenic alterations: Intensive agricultural practices and organic pollution. Sci. Total Environ. 2005, 341, 265-279. [CrossRef]

46. Wang, X.H.; Yuan, X.; Hou, Z.G.; Miao, J.; Zhu, H.; Song, C.T. Effect of di-(2-ethylhexyl) phthalate (DEHP) on microbial biomass C and enzymatic activities in soil. Eur. J. Soil Biol. 2009, 45, 370-376. [CrossRef]

47. Zhang, Y.; Wu, X.F.; Dong, S.J.; Wang, L.; Wang, Z.G.; Wang, L.H. Effect of DEHP on soil microbial populations and enzyme activities. J. Northeast Agric. Univ. 2015, 1, 47-54.

48. Wang, J.; Lv, S.H.; Zhang, M.Y.; Chen, G.C.; Zhu, T.B.; Zhang, S.; Teng, Y.; Christie, P.; Luo, Y.M. Effects of plastic film residues on occurrence of phthalates and microbial activity in soils. Chemosphere 2016, 151, 171-177. [CrossRef] [PubMed]

49. Qi, X.; Li, T.C.; Wang, F.H.; Dai, Y.R.; Liang, W. Removal efficiency and enzymatic mechanism of dibutyl phthalate (DBP) by constructed wetlands. Environ. Sci. Pollut. Res. 2018, 25, 23009-23017. [CrossRef] [PubMed]

50. Zhou, Q.H.; Wu, Z.B.; Fu, G.P.; Cheng, S.P.; He, F. Temporal and spatial characteristics of substrate enzyme activities and bacteria physiological groups in constructed wetland. Chin. J. Environ. Sci. 2005, 26, 108-112. 